\title{
LENGTH-WEIGHT RELATIONSHIPS OF SIX FRESHWATER FISH SPECIES FROM LAKE KIRKKOJÄRVI, FINLAND
}

\author{
José Gama ${ }^{1 *}$, Maria Nyberg ${ }^{2}$ \\ ${ }^{1}$ Independent researcher, Salo, Finland \\ 2 Dept. of Geology and Mineralogy, Åbo Akademi University, Domkyrkotorget 1, 20500 Åbo, Finland \\ *Corresponding Author, Email: josephgama@yahoo.com
}

\section{ARTICLE INFO}

Received: 15 March 2017

Received in revised form: 3 October 2017

Accepted: 9 October 2017

Available online: 26 October 2017

\author{
Keywords: \\ Length-weight relationship \\ Alburnus alburnus \\ Blicca bjoerkna \\ Gymnocephalus cernua \\ Perca fluviatilis \\ Rutilus rutilus \\ Sander lucioperca
}

\begin{abstract}
Length-weight relationships (LWRs) and length-length relationships (LLRs) were determined for six fish species: Alburnus alburnus, Blicca bjoerkna, Gymnocephalus cernua, Perca fluviatilis, Rutilus rutilus and Sander lucioperca caught using a Nordic multi-mesh gill net in Lake Kirkkojärvi in Southwestern Finland in August 2015. The measurements were done using a photographic method and the dataset is available on the Comprehensive R Archive Network (CRAN). The dataset was done with a scientific catch, which showed lower limits on specimen size than the ones from fisheries. The LWRs were calculated for the total length (TL) and found to be consistent with models from Finland. The length measurements were taken to the nearest $0.01 \mathrm{~cm}$, which also allowed for juveniles to be represented in the model. The goodness of fit of the models is high, with the coefficients of determination above $95 \%$. This study is the first one to estimate LWRs of fish species for this hypereutrophic lake, and is useful for fishery managers and biologists.
\end{abstract}

Gama, J., Nyberg, M. (2017): Length-weight relationships of six freshwater fish species from Lake Kirkkojärvi, Finland. Croatian Journal of Fisheries, 75, 156-159..DOI: $10.1515 /$ cjf-2017-0020

\section{INTRODUCTION}

Lake Kirkkojärvi $\left(60^{\circ} 13^{\prime} 48.0^{\prime \prime} \mathrm{N} 23^{\circ} 25^{\prime} 48.0^{\prime \prime} \mathrm{E}\right)$, part of the Kirkkojärvi Basin in Southwestern Finland, lies in a protected area and has been classified as hypereutrophic by Vaitomaa et al. (2002). Length-weight relationships (LWRs) of fish species can reflect fish-based indices (such as abundance metrics) impacted by eutrophication, which are becoming more popular in inland waters (Argillier et al., 2012). LWR models for different fish species in a particular lake and the same species in other lakes in different seasons can be compared for analysis of morphological characteristics as proxies for environmental variables. Therefore, LWRs of six fish species (Gymnocephalus cernua, Perca fluviatilis, Rutilus rutilus, Sander lucioperca, Alburnus alburnus and Blicca bjoerkna, which can be widely found in Finnish lakes) in Lake Kirkkojärvi were first studied here. To the knowledge of the authors, there are no previous LWR records for Alburnus alburnus and Blicca bjoerkna from Finland, and few studies for the other species - one from 1993 which includes LWRs for Gymnocephalus cernua, Perca fluviatilis, Rutilus rutilus and Sander lucioperca, one from 2009 with LWRs for Gymnocephalus cernua and one from 1988 with LWRs for Sander lucioperca (Froese and Pauly, 2015). Only eight lakes (four in Southern and four in Northern Finland) are represented in the existing studies, and one third of the data 
is considered doubtful at www.fishbase.org. Consequently, this study is an update and extension of LWRs of fish species in Finland.

The dataset used in this study can be downloaded from: https://cran.rproject.org/web/packages/fishkirkko2015/ index.html

\section{MATERIAL AND METHODS}

On 24 August 2015, 282 specimens caught with Nordic multi-mesh gill net were measured using a photographic method to the nearest $0.01 \mathrm{~cm}$ for total length (TL). The weight was measured with a calibrated electronic scale. The specimens were removed from the nets and kept wet and cool with water and ice before being measured.

The parameters for the LWR models were estimated by linear regression on log-transformed data, using the statistical environment $R$ ( $R$ Development Core Team, 2009). The LWR model is a function of length $(L), \operatorname{LWR}(L)=a L^{b}$.

The inclusion of early juveniles is not recommended (Le Cren, 1951; Carlander, 1969; Murphy et al., 1991; Safran, 1992; Froese et al., 2011) and several LWR models might be estimated for different development stages (Froese, 2011). However, creating models based on development stages was not necessary as the following models have good or reasonable coefficients of determination.

Table 1. Statistics and estimated parameters of length-weight relationships (LWRs) based on total length (TL) for six freshwater fish species from Lake Kirkkojärvi

\begin{tabular}{ccccccccc}
\hline \hline Species & $\mathrm{n}$ & $\begin{array}{c}\text { Length range } \\
(\mathrm{cm})\end{array}$ & $\begin{array}{c}\text { Weight } \\
\text { range }(\mathrm{g})\end{array}$ & $\mathrm{a}$ & $95 \% \mathrm{Cl} \mathrm{a}$ & $\mathrm{b}$ & $95 \% \mathrm{Cl} \mathrm{b}$ & $\mathrm{r}^{2}$ \\
\hline $\begin{array}{c}\text { Perca fluviatilis } \\
\begin{array}{c}\text { Gymnocephalus } \\
\text { cernua }\end{array}\end{array}$ & 57 & $5.34-25.76$ & $1.2-191.3$ & 0.008 & $0.007-0.011$ & 3.012 & $2.898-3.126$ & 0.981 \\
$\begin{array}{c}\text { Sander lucioperca } \\
\text { Slicca bjoerkna }\end{array}$ & 26 & $6.95-11.06$ & $1.0-12.6$ & 0.009 & $0.005-0.017$ & 2.998 & $2.702-3.295$ & 0.959 \\
Alburnus alburnus & 61 & $5.18-35.48$ & $1.5-334.6$ & 0.006 & $0.005-0.007$ & 3.027 & $2.944-3.110$ & 0.996 \\
Rutilus rutilus & 54 & $6.95-15.77$ & $2.2-23.0$ & 0.006 & $0.004-0.008$ & 3.013 & $2.889-3.137$ & 0.974 \\
\hline \hline
\end{tabular}

$\mathrm{n}$, number of individuals; TL, total length; $\mathrm{Cl}$, confidence intervals; $\mathrm{a}$, intercept; $\mathrm{b}$, slope; $\mathrm{r}^{2}$, coefficient of determination

Table 2. Statistics and estimated parameters of length-length relationships $(Y=a+b X)$ based on total length (TL), standard length (SL) and fork length (FL) for six freshwater fish species from Lake Kirkkojärvi

\begin{tabular}{|c|c|c|c|c|}
\hline Species & $\mathbf{n}$ & Equation & $95 \% \mathrm{Cl} b$ & $r^{2}$ \\
\hline \multirow{4}{*}{ Perca fluviatilis } & \multirow{3}{*}{57} & $\mathrm{TL}=0.258+1.178 \mathrm{SL}$ & $1.166-1.190$ & 0.999 \\
\hline & & $S L=-0.842+0.953 \mathrm{FL}$ & $0.946-0.960$ & 0.999 \\
\hline & & $\mathrm{FL}=0.788+0.889 \mathrm{TL}$ & $0.881-0.897$ & 0.999 \\
\hline & \multirow{4}{*}{21} & $\mathrm{TL}=0.584+1.18 \mathrm{SL}$ & $1.143-1.216$ & 0.996 \\
\hline \multirow[t]{3}{*}{ Gymnocephalus cernua } & & $\mathrm{SL}=-0.558+0.95 \mathrm{FL}$ & $0.934-0.967$ & 0.999 \\
\hline & & $\mathrm{FL}=0.402+0.887 \mathrm{TL}$ & $0.860-0.915$ & 0.996 \\
\hline & & $\mathrm{TL}=1.993+1.175 \mathrm{SL}$ & $1.162-1.188$ & 0.999 \\
\hline \multirow[t]{3}{*}{ Sander lucioperca } & \multirow[t]{3}{*}{26} & $S L=-1.021+0.949 \mathrm{FL}$ & $0.941-0.958$ & 1 \\
\hline & & $F L=-0.627+0.896 T L$ & $0.891-0.901$ & 1 \\
\hline & & $T L=-0.389+1.296 \mathrm{SL}$ & $1.282-1.310$ & 0.998 \\
\hline \multirow[t]{3}{*}{ Blicca bjoerkna } & \multirow[t]{3}{*}{61} & $\mathrm{SL}=-2.280+0.947 \mathrm{FL}$ & $0.933-0.961$ & 0.997 \\
\hline & & $\mathrm{FL}=3.008+0.812 \mathrm{TL}$ & $0.802-0.822$ & 0.998 \\
\hline & & $\mathrm{TL}=2.246+1.197 \mathrm{SL}$ & $1.180-1.215$ & 0.996 \\
\hline \multirow[t]{3}{*}{ Alburnus alburnus } & \multirow[t]{3}{*}{66} & $S L=-1.206+0.932 \mathrm{FL}$ & $0.916-0.948$ & 0.995 \\
\hline & & $\mathrm{FL}=-0.064+0.891 \mathrm{TL}$ & $0.878-0.904$ & 0.996 \\
\hline & & $\mathrm{TL}=1.560+1.245 \mathrm{SL}$ & $1.209-1.282$ & 0.989 \\
\hline \multirow[t]{2}{*}{ Rutilus rutilus } & \multirow[t]{2}{*}{54} & $S L=-1.098+0.921 \mathrm{FL}$ & $0.897-0.945$ & 0.991 \\
\hline & & $\mathrm{FL}=1.243+0.860 \mathrm{TL}$ & $0.840-0.880$ & 0.993 \\
\hline
\end{tabular}

n, number of individuals; TL, total length; SL, standard length; FL, fork length; Cl, confidence intervals; ${ }^{2}$, coefficient of determination. 


\section{RESULTS AND DISCUSSION}

282 specimens from six species were measured to estimate LWRs. The coefficient of determination might indicate the presence of outliers if it is much lower than 95\% (Froese et al., 2011). In our study, the coefficients of determination were all above 95\%, which means that the model is a good representation of the data. The $r^{2}$ for Gymnocephalus cernua and Rutilus rutilus is close to $95 \%$, for Alburnus alburnus is close to $97 \%$ and for the rest above $98 \%$.

The statistics and calculated parameters of LWRs based on TL are shown in Table 1. For TL, a ranged from 0.00579 to 0.01195 which is close to 0.01 , characteristic of streamlined-shaped fishes (Froese, 2006); b ranged from 2.848 to 3.027 , within the expected range of $2.5<b<3.5$ (Froese et al., 2011). The models benefit with the inclusion of juveniles by being more reliable as they predict the results for low lengths without extrapolating. The number and mass of juvenile fish might be an important variable in a hypereutrophic lake as this one or for health, diversity and other indices (Sulić-Šprem et al., 2012), and consequently recent studies are focusing on juveniles (Peyton, K. A. et al., 2016).

The models are consistent with the Finnish models from fishbase (Froese and Pauly, 2015), except for Rutilus rutilus which has $a b$ parameter lower than any of the fishbase models (a less steep curve results in an estimated weight lower than any other model), according to the data at the time of publication.

For all species, except Rutilus rutilus, $b$ is very close to 3 , meaning isometric growth, with both small and big specimens in the sampled populations having the same form and condition (Froese et al., 2011). Rutilus rutilus has $b$ lower than 3 , meaning negative allometric growth, with the specimens growing more in length than in height or width. The specimens of Rutilus rutilus were young, possibly biasing the model as this species grows faster during the first year of life and then the growth rate decreases until the sixth year, when it stabilizes (Papageorgiou, 1979).

The LLRs are highly correlated, with $r^{2}$ very close to 1. Both LWRs and LLRs from this study will be useful to biology, management and conservation work in Finland.

\section{ACKNOWLEDGMENTS}

The authors would like to thank Mr. Veikko Laine from the Kiskon Kirkkojärven Hoitoyhdistys ry and Mr. Chris Karppinen and Mr. Olli Ylönen from L-S Kalatalouskeskus ry. This study was independently funded.
Sažetak

\section{DUŽINSKO-MASENI ODNOSI ŠEST SLATKOVODNIH VRSTA RIBA IZ JEZERA KIRKKOJÄRVI U FINSKOJ}

Dužinsko-maseni odnosi i dužinsko-dužinski odnosi određeni su za šest vrsta riba: ukliju (Alburnus alburnus), krupaticu (Blicca bjoerkna), balavca (Gymnocephalus cernua), grgeča (Perca fluviatilis), bodorku (Rutilus rutilus) i smuđa (Sander lucioperca) ulovljenih pomoću nordijske mreže u jezeru Kirkkojärvi u jugozapadnoj Finskoj u kolovozu 2015. godine. Mjerenja su provedena pomoću fotografske metode i skup podataka je dostupan na Comprehensive $R$ Archive Network (CRAN). Podaci su dobiveni znanstvenim ulovom koji je pokazao niže granice veličine uzoraka od onih iz ribarstva. Dužinsko-maseni odnosi su izračunati za totalnu dužinu te je utvrđeno da su u skladu s podacima iz Finske. Mjerenje dužine odvijalo se na najbližu dužinu od $0,01 \mathrm{~cm}$, što je omogućilo da i mlađ bude zastupljena u modelu. Sposobnost prilagodbe modelu je visoka, s koeficijentom determinacije većim od 95\%. Ovo istraživanje je prvo koje procjenjuje dužinskomasene odnose ribljih vrsta za ovo hipereutrofno jezero i korisno je za ribarsku proizvodnju i biologe.

Ključne riječi: dužinsko-maseni odnosi, Alburnus alburnus, Blicca bjoerkna, Gymnocephalus cernua, Perca fluviatilis, Rutilus rutilus, Sander lucioperca

\section{REFERENCES}

Argillier, C., Causse, S., Gevrey, M., Pédron, S., De Bortoli, J., Brucet, S., Emmrich, M., Jeppesen, E., Lauridsen, T., Mehner, T., Olin, M., Rask, M., Volta, P., Winfield, I. J., Kelly, F., Krause, T., Palm, A., Holmgren, K. (2013): Development of a fish-based index to assess the eutrophication status of European lakes. Hydrobiologia, 704, 1, 193-211.

Carlander, K. D. (1969): Handbook of freshwater fishery biology, Vol. 1. Ames, lowa State University Press. 752 pp.

Froese, R. (2006): Cube law, condition factor and weightlength relationships: history, meta-analysis and recommendations. Journal of Applied Ichthyology, 22, 4, 241 253.

Froese, R., Tsikliras, A. C., Stergiou, K. I. (2011): Editorial note on weight-length relations of fishes. Acta Ichthyologica et Piscatoria, 30, 10, 14-11.

Froese, R., Pauly, D. (2015): FishBase. World Wide Web electronic publication,cited 2015 September 17. Available from: http://www.fishbase.org

Le Cren, E. D., (1951): The length-weight relationship and seasonal cycle in gonad weight and condition in the 
perch (Perca fluviatilis). Journal of Animal Ecology, 20, 2, 201-219.

Murphy, B. R., Brown, M. L., Springer, T. A. (1991): Evaluation of the relative weight $(\mathrm{Wr})$ index, with new application to walleye. North American Journal of Fisheries Management, 10, 1, 85-97.

Papageorgiou, N. K. (1979): The length weight relationship, age, growth and reproduction of the roach Rutilus rutilus (L.) in Lake Volvi. Journal of Fish Biology, 14, 6, 529-538. Peyton, K. A., Sakihara, T. S., Nishiura, L. K., Shindo, T. T., Shimoda, T. E., Hau, S., Akiona, A., Lorance, K. (2016): Length-weight relationships for common juvenile fishes and prey species in Hawaiian estuaries. J. Appl. Ichthyol. 32, 499-502. DOI, http://dx.doi.org/10.1111/jai.

R Development Core Team (2009): R: A Language and Envi- ronment for Statistical Computing. R Foundation for Statistical Computing, Vienna, Austria.

Safran, P., (1992): Theoretical analysis of the weight-length relationship in fish juveniles. Marine Biology, 112, 4, 545551.

Sulić-Šprem, J., Kožul, V., Antolović, N., Glavić, N., Bartulović, V. (2012): The quantitative-qualitative content of juvenile fish at the mouth of the rivers Neretva and Mala Neretva during the summer-autumn period. Croatian Journal of Fisheries. $70,3,28-40$.

Vaitomaa, J., Repka, S., Saari, L., Tallberg, P., Horppila, J., Sivonen, K. (2002): Aminopeptidase and phosphatase activities in basins of Lake Hiidenvesi dominated by cyanobacteria and in laboratory grown Anabaena. Freshwater Biology, 47, 1582-1593. 